Marquette University

e-Publications@Marquette

$2-1-1996$

\title{
The Influence of Professional Investors on the Failure of Management Buyout Attempts
}

Sarah Peck

Marquette University, sarah.peck@marquette.edu

Accepted version. Journal of Financial Economics, Vol. 40, No. 2 (February 1996): 267-294. DOI. NOTICE: this is the author's version of a work that was accepted for publication in Journal of Financial Economics. Changes resulting from the publishing process, such as peer review, editing, corrections, structural formatting, and other quality control mechanisms may not be reflected in this document. Changes may have been made to this work since it was submitted for publication. A definitive version was subsequently published in Journal of Financial Economics, VOL 40, ISSUE 2, (February 1996) DOI. 


\title{
The Influence of Professional Investors on the Failure of Management Buyout Attempts
}

\author{
Sarah W. Peck \\ College of Business Administration, University of Iowa \\ Iowa City, IA
}

\begin{abstract}
In a sample of 111 MBO offers between 1984 and 1987, almost $30 \%$ attract new blockholders. These blockholders are primarily professional investors who act to facilitate a takeover by a higher bidder, thus increasing returns to both themselves and other public shareholders. In contrast, I find little evidence that pre-existing blockholders, particularly institutional holders, affect either the offer outcome or actively participate in the buyout contest once it begins. The overall pattern of results suggests that professional investors, particularly equity-holding companies, are 'control specialists' who provide valuable services as brokers in the market for corporate control.
\end{abstract}

\section{Introduction}

Academic researchers have long recognized the incentives to acquire blocks during control contests. Jensen and Ruback (1983) are the first to point out that ' $(t)$ akeover specialists, sometimes referred to as 'raiders' -who acquire specialized expertise in takeover strategy and in ferreting out and amassing a controlling block of shares-perform an important function in facilitating transfers of control'. My research focuses on management buyout offers (MBO). I investigate the extent of block acquisitions by professional investors during these control 
contests and the role these blockholders play vis-a-vis pre-existing blockholders in the contest resolution.

Two characteristics of MBO offers make them suitable events for an initial investigation into the role of professional investors in control contests. First, in an MBO there is an inherent conflict of interest between management and shareholders over the price offered for the firm. Managers have a fiduciary duty to maximize share value. Yet, they also have an incentive to sell the firm to themselves as cheaply as possible. Researchers (see DeAngelo, DeAngelo, and Rice, 1984; Lowenstein, 1985; DeAngelo and DeAngelo, 1987; Kaplan, 1989) have discussed possible safeguards against managerial self-dealing. The acquisition of a block is one such safeguard. Professional investors who can detect managerial self-dealing might be able to extract a higher premium for both themselves and/or other shareholders.

Second, there is uncertainty that management will succeed in its bid to acquire the firm. While most research focuses on successful MBOs (see DeAngelo, DeAngelo, and Rice, 1984; Kaplan, 1989; Smith, 1990), MBO offers are not usually 'done deals' when they are announced. Kaplan (1989) documents that many MBO attempts are contested, and many fail. When an MBO fails, the firm is often taken over by a higher bidder. Uncertainty about the success of MBO attempts provides opportunities for professional investors to improve offer prices.

The results of this study show that professional investors act to improve the terms of buyout offers to shareholders. Many MBO attempts attract professional investors, particularly those in equityholding companies, who take actions to facilitate the takeover of the firm by either themselves or a third party at a higher price. Furthermore, these new blockholders seem to fill a niche in the monitoring function of outside blockholders. Pre-existing blockholders, particularly institutional holders, do not seem to affect the outcome of the offer, and do not actively participate in negotiations once the contest begins.

This study makes three contributions. First, the importance of new blockholders is demonstrated. Prior research suggests that the ex ante level of stock ownership concentration and its division between management and outsiders is important in determining the likelihood of a takeover (see Manne, 1965; Bradley, 1980; Grossman and Hart, 1980; Shleifer and Vishny, 1986; Harris and Raviv, 1988; Stulz, 
1988). In this research, the ex post changes in ownership concentration are important to the ultimate contest outcome.

Second, this study expands the notion of the set of players in the market for corporate control. Prior research has demonstrated empirically the importance of the role of managers, existing blockholders (see Jensen and Ruback, 1983; Jensen and Warner, 1988; and the references therein), competitive bidders (see Bradley, Desai, and Kim, 1988), and boards of directors (see Byrd and Hickman, 1992). The evidence presented here shows that professional investors are also active, influential players in control contests.

Third, this study builds on similar findings by prior researchers. Mikkelson and Ruback (1985) investigate a sample of block acquisitions of $5 \%$ or more of a company's stock, and find that about half are associated with a takeover proposal. While block acquisitions are usually made by companies that eventually take over the firm, some block acquisitions are made by professional investors (defined as frequent purchasers) who rarely take over the firm. Mikkelson and Ruback (1985) do not investigate whether these investors acquire shares in anticipation of a takeover or to actively participate in the contest; this study does. Holderness and Sheehan (1986) find that after there. has been a block acquisition by a professional investor, some firms are eventually taken over by a third party, but do not document the actions these investors take to facilitate the takeover. Holderness and Sheehan's study is also limited to six controversial investors/'raiders'. This study adds to our knowledge of the role of takeover specialists by reporting the details of the types of professional investors (both frequent acquirers or 'raiders' and equityholding companies) and the actions they take during MBO events. The outline of the paper is as follows. Section 2 describes the sample, measurement, and definition of outside blockholdings, and characteristics of MBO contests. Section 3 documents the extent of changes in outside blockholdings around an MBO offer, and presents evidence on the role professional investors play in the buyout contest. Section 4 concludes.

\section{The sample}

This section describes the sample design and data collection. I provide a detailed description on the various definitions of outside

Journal of Financial Economics, Vol. 40, No. 2 (February 1996): pg. 267-294. DOI. This article is (C Elsevier and permission has been granted for this version to appear in e-Publications@Marquette. Elsevier does not grant permission for this article to be further copied/distributed or hosted elsewhere without the express permission from Elsevier. 
NOT THE PUBLISHED VERSION; this is the author's final, peer-reviewed manuscript. The published version may be accessed by following the link in the citation at the bottom of the page.

blockholders that I use in this study. I also provide descriptive statistics of MBO contests.

\subsection{Sample design and data}

I obtain a preliminary sample of 90 management buyout attempts from 1984 to 1987 from the Dow Jones News/Retrieval Service by searching for articles containing the following words or phrases: 'management buyout', 'leveraged buyout', 'LBO', 'MBO', 'going private', and 'taken private'. An MBO attempt is defined as any announcement in which top management, either alone or with a group of equity investors, makes an offer to buy the firm. Forty-eight additional management buyout attempts are identified using a sample provided by Steven Kaplan. ${ }^{1}$ Seventeen firms are eliminated because of insufficient return data on either the Center for Research in Security Prices (CRSP) or CRSP/NASDAQ tapes to estimate market model returns. Eight firms are eliminated because they are not reported by Standard \& Poor's. Therefore, data on institutional shareholdings are unavailable. Five firms are eliminated because The Insider's Chronicle did not report data on inside holdings (The Insider's Chronicle began publishing after the relevant dates). The final sample consists of 111 firms and includes buyouts initiated by both management and outside parties.

The primary sources of data for events during the MBO contest are the Wall Street Journal and the Dow Jones News Wire. For each firm in the sample I read all articles and news releases for the year prior to the initial buyout announcement to two years after or when the firm becomes private and ceased to have its activities reported in the financial press. I collect event dates and other relevant data for each event for the following general categories: initial buyout announcement, management actions, actions by independent directors, actions by minority shareholders, actions by outside bidders, and the buyout outcome. I also collect data on the level of inside holdings and total equity value. I obtain data on the level of inside ownership concentration the year prior to the MBO offer from the firm's proxy statement in the year prior to the MBO offer. Since proxy statements do not always occur one year prior to the offer, I adjust these data using The Insider's Chronicle. I obtain data on total equity value the month prior to the initial buyout offer using share price and

Journal of Financial Economics, Vol. 40, No. 2 (February 1996): pg. 267-294. DOI. This article is (C) Elsevier and permission has been granted for this version to appear in e-Publications@Marquette. Elsevier does not grant permission for this article to be further copied/distributed or hosted elsewhere without the express permission from Elsevier. 
NOT THE PUBLISHED VERSION; this is the author's final, peer-reviewed manuscript. The published version may be accessed by following the link in the citation at the bottom of the page.

shares outstanding data from either the CRSP or CRSP/NASDAQ tapes, or Standard \& Poor's Monthly Security Owner's Stock Guide.

\subsection{Data on outside blockholders}

Data on outside block holders are available because of SEC disclosure requirements. The SEC requires that institutional investors who own, in aggregate, $\$ 100$ million or more of equity securities must file a $13 \mathrm{~F}$ form. Institutional investors who own $5 \%$ or more of the shares outstanding of an individual firm (and when the investment is made in the ordinary course of business and without the intention of changing or influencing control of the firm) must file a $13 \mathrm{G}$ form. Both forms must be filed quarterly. Institutional investors typically own $1 \%$ of a firm's shares outstanding (see Brickley, Lease, and Smith, 1988); in my sample the average holding is $1.48 \%$. (Because of potential reporting lags for institutional holdings, all tests are rerun using the highest level of institutional holdings obtained in either the year prior to the MBO offer or the two years after the MBO offer. The results are qualitatively the same for all tests.) An individual investor or company who owns $5 \%$ of the shares outstanding must file a schedule 13D within ten days of reaching the $5 \%$ threshold. The investor must also state whether the purpose of the acquisition is to change or influence control of the firm. Any changes in the initial 13D, 13F, or $13 \mathrm{G}$ form must be reported in amended filings. The SEC also requires outside investors who own a block or $5 \%$ or more (whether a $13 \mathrm{G}$ or $13 \mathrm{D}$ filer) to disclose their holdings in the firm's annual proxy statement.

Both 13D and institutional blockholders are included in this investigation. Pre-existing blockholders are those who own blocks at the time of the announcement of the MBO offer. Since professional investors are likely to acquire a block either to anticipate an offer or to precipitate an offer, I distinguish between pre-existing blockholders who have held a block for at least a year and those that have only recently acquired a block. Old blockholders are defined as investors who own a block 12 months prior to the MBO offer. New pre-offer blockholders are defined as investors who make their initial block investment during the year before the MBO offer. New post-offer blockholders are those investors who make their initial investment after the MBO offer. All of my hypotheses concern the role of new post-offer blockholders in the contest.

Journal of Financial Economics, Vol. 40, No. 2 (February 1996): pg. 267-294. DOI. This article is (C Elsevier and permission has been granted for this version to appear in e-Publications@Marquette. Elsevier does not grant permission for this article to be further copied/distributed or hosted elsewhere without the express permission from Elsevier. 
Data on the level of old institutional holdings are obtained from Standard \& Poor's Monthly Security Owner's Stock Guide. I obtain data on the level of old 13D outside blockholdings from the firm's proxy statement in the year prior to the initial buyout announcement. Because not all proxy statements occur exactly one year prior to the MBO offer, all data are adjusted using the Dow Jones News Wire or the Wall Street Journal. I assume that all 5\% investors listed in the firm's proxy statement that are not institutional investors are 13D filers. [I identify institutional investors using the classifications in Brickley, Lease, and Smith (1988).] This method potentially understates the level of old 13D blockholdings. I rerun tests, assuming all 5\% blockholders reported in the proxy statement are 13D filers. The results are qualitatively the same for all tests. Data on new blockholders are taken from reports in the Dow Jones News Wire or the Wall Street Journal of block acquisitions.

Using reports of $13 \mathrm{D}$ filings rather than the actual filings themselves can create potential data problems. First, to the extent that not all SEC filings are reported in the Wall Street Journal or the Dow Jones News Wire, new block acquisitions are under-reported in the sample. Second, reporting lags can lead to some new pre-offer blockholders being misclassified as new post-offer blockholders. To correct for this problem, I assume a one- month lag for all block acquisitions or changes in blockholdings reported in the financial press. In addition, I show in Table 3 the adjusted number of days between the MBO announcement and the first report of the 13D filing for new post-offer blockholders. On average, new post-offer block acquisitions occur between four to five months after the MBO announcement, indicating that any remaining reporting lags are unlikely to lead to misclassifications.

I also analyze changes in blockholdings over the event period. Data on monthly changes in 13D filings are taken from reports of amended 13D filings in the Wall Street Journal or an announcement over the Dow Jones New Wire. Data on changes in individual institutional investor holdings are not available. However, data on monthly changes in total institutional holdings are available from Standard \& Poor's Monthly Security Owner's Stock Guide.

I also search the financial press for changes in institutional holdings. Using the classifications in Brickley, Lease, and Smith (1988), I find a few instances of 13D filings by institutional investors

Journal of Financial Economics, Vol. 40, No. 2 (February 1996): pg. 267-294. DOI. This article is (c Elsevier and permission has been granted for this version to appear in e-Publications@Marquette. Elsevier does not grant permission for this article to be further copied/distributed or hosted elsewhere without the express permission from Elsevier. 
and report these in Table 4. I find only one report of a block acquisition by a $13 \mathrm{G}$ filer, who was later sued by the firm for not filing a $13 \mathrm{D}$.

The type of blockholder is also reported, i.e., whether the blockholder is a professional investor, institution, miscellaneous corporation, or individual. Data on old blockholder types for 5\% blockholders (whether 13G or 13D) are obtained from the firm's proxy statement. Data on new blockholder types are taken from reports in the financial press. Data on the types of actions blockholders take (other than an acquisition of shares) are obtained from reports in the financial press.

\subsection{Sample characteristics of $M B O$ contests}

Table 1 shows the possible outcomes of MBO offers. One of its most interesting findings is the low success rate of management buyout attempts. Management successfully acquires the firm only $66 \%$ of the time. If the management buyout fails, the firm is taken over by an outside party $63 \%$ of the time. Intervening events between the management buyout offer and the final acquisition of the firm are likely to affect the probability that management successfully acquires the firm. In my sample, buyout transactions take an average of seven months to complete. The lengthy time needed to complete the buyout reinforces the notion that management buyout offers are often contested, and that the transition of the firm from public to private status is a protracted process.

To understand the contest, it is important to have in mind the process and its stylized facts. (Table 2 reports the frequency and chronology of events during the buyout contest, and the stock price reaction to these events.) An MBO contest begins with the announcement that management, either alone or with a group of equity investors, has made an offer to buy the firm. Simultaneously, a committee of independent directors is usually formed to evaluate the offer and to consider competing bids, often with the help of an independent investment banker and/or lawyers retained by the committee. The formation of a committee of independent directors is reported $64 \%$ of the time.

After the initial offer is made, the bid can be contested by an outside third party. Twenty-three percent of the time an outside third party (other than a blockholder) makes a higher offer to acquire the 
firm. Most of these bids occur within three months of the MBO offer and are associated with a positive stock price reaction of $7.89 \%$.

Shareholders can also contest the offer. Minority shareholders litigate the fairness of the MBO offer or the fairness of antitakeover defenses $40 \%$ of the time. The stock price reaction associated with minority shareholder litigation is negative but insignificant, which suggests such litigation is ineffective in increasing the offer price. In contrast, actions, other than the acquisition of the block itself, taken by either old or new blockholders, which occurs about $30 \%$ of the time, are associated with a positive stock price reaction of $13.05 \%$. When I exclude announcements that include reports of block acquisitions, the remaining announcements (that a blockholder has taken some type of action after the MBO offer) are associated with a statistically significant three-day abnormal return of $15.11 \%$. A blockholder as a large shareholder is likely to have more leverage over the offer. In addition to litigating the fairness of either the offer or the antitakeover defenses, a blockholder could achieve membership on the board and meet with executives, thereby gaining access to nonpublic company information. Such inside information can allow him to devise a better restructuring plan under which either management offers a higher premium or the firm is sold to a higher bidder. Blockholders can also exert pressure on management's bid by making a higher offer for the firm themselves. Furthermore, opportunities to achieve a higher premium through any of these actions is likely to attract new blockholders. Table 2 shows that announcements of a post-offer block acquisition occur about $30 \%$ of the time and are associated with a positive stock price reaction of $5.49 \%$.

The board of directors can also contest management's offer. The evidence shows that the board does so infrequently; only $8 \%$ of the time is there an announcement that the board has rejected management's offer. However, it is likely that management does not make a buyout offer without first getting the board's approval. The few announcements of the board rejecting management's offer are associated with a significantly positive stock price reaction. This is consistent with previous research, which finds that independent directors provide an important monitoring function during control contests (see Byrd and Hickman, 1992; Brickley, Coles, and Terry, 1994).

Journal of Financial Economics, Vol. 40, No. 2 (February 1996): pg. 267-294. DOI. This article is (C Elsevier and permission has been granted for this version to appear in e-Publications@Marquette. Elsevier does not grant permission for this article to be further copied/distributed or hosted elsewhere without the express permission from Elsevier. 
NOT THE PUBLISHED VERSION; this is the author's final, peer-reviewed manuscript. The published version may be accessed by following the link in the citation at the bottom of the page.

The management group can respond in several ways to a contested offer. Management either revises its offer and/or takes some type of antitakeover action, such as litigation of the outside bidder. For all the MBOs in the sample, management revises its offer about half the time; announcements of these revisions are accompanied with a positive stock price reaction of $7.87 \%$. Management also takes actions to resist a takeover $16 \%$ of the time. Managerial resistance is defined as taking anyone of the following actions: adopting an antitakeover amendment; litigating an outside bidder; and increasing management's effective stake by buying back shares, debt for equity swap, repurchase of convertible preferred or convertible debt for cash, private placement of equity, or repurchase of shares from an investor. Dann and DeAngelo (1988) show that buyback capital transactions can be defensive in nature. However, it is also likely that some of these transactions are related to the financing of the buyout and are misclassified as resistive. Table 2 shows that many managers take countering actions before the MBO offer which suggests that management anticipates its offer will be contested.

Thus, the typical scenario of the MBO contest described above provides a context in which to evaluate the influence of professional investors on the outcome. The preliminary evidence indicates that other players - besides professional investors, i.e., outside third parties, management, minority shareholders and independent directors - can be involved in setting the buyout premium and determining who ultimately acquires the firm.

\section{Evidence on the role of professional investors during MBO contests}

This section further explores the role of professional investors, while controlling for the participation of other players in the contest.

\subsection{Increases in outside blockholdings around $M B O$ offers}

Changes in the level of both institutional and 13D blockholdings (as a percentage of shares outstanding) are shown in Fig. 1. Both initial and amended 13D filings are included in the measure of 13D holdings. A total of 263 13D filings are reported in the sample; 204 of these are purchase transactions and 59 are sales transactions. The

Journal of Financial Economics, Vol. 40, No. 2 (February 1996): pg. 267-294. DOI. This article is (C Elsevier and permission has been granted for this version to appear in e-Publications@Marquette. Elsevier does not grant permission for this article to be further copied/distributed or hosted elsewhere without the express permission from Elsevier. 
majority of these transactions are open market. Only 21 filings are reported as negotiated trades. I calculate total 13D blockholdings as the sum of each 13D blockholder's highest holdings within that month. With month zero denoting when the offer is announced, both types of blockholdings are shown from month -12 to month +24 , or until the buyout is completed. I adjust the percentage of shares owned by outside blockholders for any changes in total shares outstanding. Reports of 13D filings are adjusted for a one-month lag, and reports of institutional holdings are adjusted for a three-month lag.

Fig. 1 shows that total outside block holdings increase around MBO offers, peaking three months before the offer. The decline in outside ownership concentration afterwards roughly corresponds to the completion rate of the buyouts. Blockholdings of 13D filers increase by about $18 \%$, from $14.54 \%$ at month -12 to the highest average value of $17.11 \%$ in month 2 . The increase in 13D holdings after the MBO announcement in Fig. 1 appears erratic because both the rate of buyout completions and the rate of block acquisitions vary across firms. Blockholdings for institutions increase by $16 \%$, from $31.53 \%$ at month -12 to the highest average value of $37.44 \%$ at month -3 .

Table 3 reports the average size of a block acquisition by both new and old blockholders. The table shows that MBO offers attract new blockholders, who account for the majority of the block acquisitions both before and after the MBO announcement. Fifty-five new investors acquire a block before the offer, while only four old blockholders increase the size of their block. Thirty-five new block acquisitions are made after the offer, while new pre-offer blockholders increase the size of their holdings only eight times and old blockholders do so only four times.

Table 3 shows that there are incentives for new investors to acquire a block both before and after the MBO offer. There are three reasons why it is difficult to test the incentives for a block acquisition before the offer. First, a random sample of firms is needed to test whether a block acquisition increases the probability of an MBO offer; I have a nonrandom sample of MBO offers. Second, it is difficult to test whether pre-offer blockholders increase the initial offer price. For this test, I need the price that management would have offered without pressure from the blockholder; this price is unobservable. Third, many cases in which pre-offer blockholders facilitate a takeover are not likely to be included in my sample. Management is unlikely to make an MBO

Journal of Financial Economics, Vol. 40, No. 2 (February 1996): pg. 267-294. DOI. This article is (C) Elsevier and permission has been granted for this version to appear in e-Publications@Marquette. Elsevier does not grant permission for this article to be further copied/distributed or hosted elsewhere without the express permission from Elsevier. 
offer if there is a high probability that such an offer will fail. However, I am able to provide evidence on the types of blockholders who acquire blocks before the MBO announcement and the type of actions they take. The evidence suggests that blockholders who acquire a block before the MBO offer play an important role in precipitating the offer.

\subsection{Control versus arbitrage}

MBO offers can create profit opportunities for two types of professional investors: arbitragers (or inside traders) or control specialists. While both types can influence the premium by implicitly refusing to tender/vote their shares at the original offer price, control specialists distinguish themselves by taking additional actions (such as litigating the fairness of the offer) that further escalate the premium. Thus, the distinction between arbitrage and control motives for professional investors is important, because each has a different implication for shareholder wealth. Furthermore, when investors trade exclusively for arbitrage or inside information reasons it is empirically difficult to infer the direction of causality between block acquisitions by professional investors and higher offers. Observing block acquisitions prior to higher offers is consistent with both the hypotheses that blockholder pressure causes higher offers and that information about higher offers (whether obtained illegally or through arbitrage expertise) causes block acquisitions. When blockholders take actions, it is easier to infer causality; rational blockholders will not take costly actions unless they expect to be compensated by an increase in the offer premium as a result of these actions.

The two motivations for block ownership are not mutually exclusive, but professional investors who take actions during the buyout contest cannot be strictly classified as arbitragers. I classify investors who take no action during the buyout contest as passive blockholders and blockholders who take actions during the buyout contest as active blockholders. Some passive blockholders, however, could be misclassified, since blockholders can take unreported actions to influence the outcome of the contest.

Table 4 reports the different types of blockholders who own shares either before or after the MBO offer. This table contains two findings that show most of the time, block acquisitions are made by control specialists in response to the MBO offer. First, the majority of investors acquiring shares are best characterized as control

Journal of Financial Economics, Vol. 40, No. 2 (February 1996): pg. 267-294. DOI. This article is @ Elsevier and permission has been granted for this version to appear in e-Publications@Marquette. Elsevier does not grant permission for this article to be further copied/distributed or hosted elsewhere without the express permission from Elsevier. 
specialists/arbitragers (24 out of 35): They are professional investors who repeatedly acquire blocks in firms involved in control contests. Table 4 shows that these blockholders are primarily frequent acquirers and equity-holding companies. ${ }^{2}$ Furthermore, both frequent acquirers and equity-holding companies have been characterized as control specialists and/or arbitragers elsewhere; thus the characterization of blockholders as control specialists and/or arbitragers is not unique to this study (see Holderness and Sheehan, 1985; Mikkelson and Ruback, 1985; Miller, 1986). Second, about half of these new post-offer block acquisitions are made by investors who take actions during the contest (17 active versus 18 passive). In addition, Table 4 shows that new pre-offer blockholders are most likely to be control specialists/arbitragers who are active during the contest.

Table 4 compares the types of new post-offer investors to preexisting blockholders. In contrast to new blockholders, old blockholders are more likely to be institutions. ${ }^{3}$ Such investors make up 89 out of 143 old blockholders. Table 4 also shows that institutional investors are less likely to increase their holdings during the contest. Only nine old blockholders acquire more shares either in the year before the offer or afterwards. SEC filing requirements for institutional investors could explain why old blockholders do not acquire additional shares during MBO contests. The SEC requires that institutional filers do not intend to change or influence control of the firm. These requirements are likely to decrease incentives to develop expertise in identifying low offers and/or to negotiate for a better offer. In addition, other regulations could rule out block acquisitions by institutional investors (see Roe, 1990). Finally, Table 4 shows that old blockholders are less likely to take observable actions during the MBO contest. Only 13 out of 143 old block holders are active compared with 45 out of 90 new blockholders.

Table 5 reports the type of actions that new blockholders take. Table 5 also provides direct evidence in support of causality as well as insight into the methods blockholders use to influence both the buyout price and the buyout outcome. Table 5 includes the frequency of the different types of actions taken which are cross-tabulated with the types of blockholders in the sample. Table 5 shows that the investors I call 'control specialists/arbitragers' account for the majority of the actions taken by new post-offer blockholders. Bidding is the action most often taken by new post-offer blockholders ( $49 \%$ of the time)

Journal of Financial Economics, Vol. 40, No. 2 (February 1996): pg. 267-294. DOI. This article is (C) Elsevier and permission has been granted for this version to appear in e-Publications@Marquette. Elsevier does not grant permission for this article to be further copied/distributed or hosted elsewhere without the express permission from Elsevier. 
and can reflect the blockholders' attempt to take over the firm at a higher price than management offered. (Blockholders do, in fact, successfully take over the firm about $15 \%$ of the time.) Bidding can also be used as a tactic to elicit a higher bid. Professional investors can signal to other bidders the price at which they will relinquish control of their shares. Other bidders will match the blockholder's bid as long as the blockholder's offer is credible. Control specialists, i.e., frequent acquirers, have a reputation for making value-increasing changes in the firm by shaking up existing management, by finding a new management team, or, as a last resort, by acquiring the firm and making the changes themselves (see Holderness and Sheehan, 1985).

Anecdotal evidence illustrates this alternative view: In the case of the Fruehauf MBO attempt, Asher Edelman acquired a block, then made a higher bid for the firm after management allied with a group of investors led by Merrill Lynch made a buyout offer. The Wall Street Journal (August 8, 1986) reports: 'Indeed, sources said that Edelman and his advisors were 'shocked' at the Merrill Lynch group's failure to increase its offer. The Edelman Group had publicly indicated a willingness to bid \$49.50, and one source said they had expected the Merrill Lynch Group to bid at least \$50 a share, outbidding Edelman and guaranteeing the New York investor a large profit on his holdings. Instead, the Edelman group may now find itself owning all of Fruehauf.' Subsequently, a higher bid was made. Edelman did not end up acquiring the firm.

The second most frequent action (15\% of the time) is opposition to the MBO offer via proxy fights, litigation, or publicly stating the new blockholders are against the offer. This action can increase the blockholder's bargaining position with management (the blockholder can agree to stop his actions in exchange for a higher offer) or by delaying the completion of the $\mathrm{MBO}$, it can give higher bidders time to emerge (see Jarrell, 1985).

Third, blockholders can elicit a higher bid by devising a superior restructuring plan that warrants a higher premium ( $20 \%$ of the time). Blockholders can state that they are working on such a plan, that they are meeting with executives and gaining access to nonpublic company records, or that they are obtaining a temporary board seat.

Actions taken to thwart the MBO offer or that reflect participation in the restructuring, can be used to elicit a higher offer from another party or as part of a takeover attempt by the control

Journal of Financial Economics, Vol. 40, No. 2 (February 1996): pg. 267-294. DOI. This article is (C Elsevier and permission has been granted for this version to appear in e-Publications@Marquette. Elsevier does not grant permission for this article to be further copied/distributed or hosted elsewhere without the express permission from Elsevier. 
specialist/arbitrager himself. For example, a blockholder that makes a bid for the firm also litigates management as part of his takeover strategy. However, there is no significant association between bidding and other actions taken by control specialists/arbitragers (for actions to thwart MBO attempt, chi-square $=0.027, p$-value $=0.87$, and for participation in restructuring, chi-square $=0.285, p$-value $=0.59$ ) . This finding suggests that occasionally, the other actions are taken as part of a takeover attempt, and sometimes they are taken to elicit a higher offer from another party.

I also investigate actions taken by new pre-offer blockholders. As Table 5 shows, investors who acquire a block before the MBO offer are active both before and after the offer. There is also no significant difference between the actions taken by investors who acquire a block before and those who acquire a block after the MBO offer. Bidding, waging a proxy fight, litigating to drop antitakeover defenses, meeting with executives, etc., are all actions that are likely to be perceived by management as a takeover threat and prompt an MBO offer. However, Table 5 shows that frequent acquirers account for more of the actions taken by new pre-offer blockholders, while equity-holding companies account for more of the actions taken by new post-offer blockholders. This finding suggests that different types of professional investors play different roles in; MBO contests; one type of investor, i.e., frequent acquirers, precipitates offers, while another, i.e., equity holding companies, contests them.

\subsection{Professional investors and pre-existing outside blockholders}

I define pre-existing blockholders as old 13D blockholders, new pre-offer blockholders, and institutional holders reported as of the month of the MBO offer. The control specialist's power depends in part on the character of those pre-existing blockholders. If pre-existing blockholders are aligned with management, they are likely to vote against the new blockholder and neutralize his voting power. In contrast, if pre-existing blockholders are not aligned with management, they have an incentive to vote for the higher offer, and thus become the newcomer's ally. However, if pre-existing blockholders are already involved in negotiating the offer, the new investor is less likely to gain from entering into negotiations; ongoing actions can already have achieved a higher premium. The incentive to

Journal of Financial Economics, Vol. 40, No. 2 (February 1996): pg. 267-294. DOI. This article is (C) Elsevier and permission has been granted for this version to appear in e-Publications@Marquette. Elsevier does not grant permission for this article to be further copied/distributed or hosted elsewhere without the express permission from Elsevier. 
be an active control specialist thus depends on the behavior of preexisting blockholders.

There is no significant correlation between a new post-offer block acquisition and the percentage of shares outstanding held by old $13 \mathrm{D}$ outside blockholders (correlation coefficient $=-0.10, p$-value $=$ $0.30)$. A new post-offer block acquisition is positively correlated with the total percentage of shares outstanding held by institutions (correlation coefficient $=0.06, p$-value $=0.56$ ). These findings suggest that both institutional holders and old 13D blockholders do not substitute for new investors in negotiating during the contest. The correlations between old 13D and institutional holdings and a new preoffer block acquisition are similar. A new pre-offer block acquisition is not significantly correlated with the level of old 13D outside blockholdings (correlation coefficient $=0.01, p$-value $=0.93$ ), but is positively correlated with the level of preexisting institutional holdings (correlation coefficient $=0.26, p$-value $=0.01$ ).

In contrast, a new post-offer block acquisition is negatively correlated with the percentage of shares outstanding held by new preoffer blockholders (correlation coefficient $=-0.14, p$-value $=0.08$ ). This finding suggests that new pre- and post-offer blockholders substitute for each other in negotiating for a higher offer. Additional evidence presented in the following sections suggests that new preoffer blockholders generate 'high' initial offers, while new post-offer blockholders contest 'low' initial offers.

\subsection{A higher buyout offer versus 'side payments'}

Professional investors can acquire a block in anticipation of receiving side payments from management and/or a higher buyout premium from either management or a third party. The best-known side payment is 'greenmail', in which management buys back such blocks at a premium above the current market price. Another practice is for management to offer blockholders participation in post-buyout equity.

Professional investors receive side payments infrequently. New post-offer blockholders who are control specialists/arbitragers participate in post-buyout equity in only three firms (however, these cases are best characterized as 'takeovers' rather than 'deals' worked out with management), and never accept some other type of side payment (see Table 5). The findings for new pre-offer blockholders 
who are control specialists/arbitragers are similar. These investors participate in post-buyout equity in only one firm, and accept some other type of side payment only three times (see Table 5).

Table 6 reports the Spearman rank correlations between a higher offer (from either management or an outside bidder other than a blockholder) after the initial MBO offer and new block acquisitions made before the higher offer. New blockholders that are corporations are differentiated from control specialists/arbitragers, since the latter are more important to the hypothesis concerning the role of professional investors in the contest. ${ }^{4}$ I make distinctions between active and passive blockholders; I also distinguish between when these actions are taken. Actions before the offer are likely to lead to higher initial offers, while actions after the offer are likely to lead to higher subsequent offers. Table 6 includes other contest events that are likely to have an effect on the probability of a higher offer. I include both events that occur in the year prior to the MBO offer and events that occur after the MBO offer but before the higher offer. I also examine the relation between pre-existing ownership structure and the likelihood of a higher offer. Variables that measure pre-existing ownership structure include inside holdings, institutional holdings, the level of old 13D blockholdings, and dummy variables for different types of new pre-offer blockholders.

Table 6 shows that, as predicted, a higher offer is significantly, positively correlated with both the post-offer acquisition of a block by a control specialist/arbitrager (either active or passive) after the MBO offer, but before the higher offer, and with a pre-offer acquisition of a block by a control specialist/arbitrager who takes actions after the offer. Size is also positively correlated with a higher offer. It is likely that larger buyouts are subject to more bidding.

Table 6 also reports the results of a multivariate logit regression. It shows that statistically the effects of a new post-offer acquisition by an active control specialist/arbitrager are only weakly significant after controlling for other variables. However, multicollinearity between a new post-offer acquisition by an active control specialist/arbitrager and other variables is likely to decrease the chance that all are found significant in a regression. A new postoffer acquisition of a block by an active control specialist/arbitrager is both positively correlated with a new post-offer acquisition by a passive control specialist/arbitrager (correlation coefficient $=0.14, p$ -

Journal of Financial Economics, Vol. 40, No. 2 (February 1996): pg. 267-294. DOI. This article is (C) Elsevier and permission has been granted for this version to appear in e-Publications@Marquette. Elsevier does not grant permission for this article to be further copied/distributed or hosted elsewhere without the express permission from Elsevier. 
value $=0.15)$ and a new pre-offer acquisition by a control specialist/arbitrager who takes actions after the offer (correlation coefficient $=0.17, p$-value $=0.07$ ) .

An alternative dependent variable is the percentage change in the premium offered. However, buyout offers sometimes consist of a mix of both cash and newly issued securities. So a percentage change in the offer cannot be easily calculated. For a subsample of firms with all cash offers $(n=59)$, I calculate a percentage change in the premium offered. For firms with a new post-offer block acquisition by an active control specialist/arbitrager the average change in the premium for cash offers is $13.91 \%$ (median $=21.54 \%, n=5$ ) but only $2.14 \%$ (median $=0 \%, n=54$ ) for firms with no new post-offer block acquisition by an active control specialist/arbitrager. This difference is statistically significant at the $7 \%$ level, using a Wilcoxon sign rank $t$-test. In contrast, for firms with a new pre-offer block acquisition by an active control specialist/arbitrager the change in the premium for cash offers (mean $=9.18 \%$, median $=0 \%, n=9$ ) is not statistically different from firms with no new pre-offer block acquisition by an active control specialist/arbitrager (mean $=2.05 \%$, median $=$ $0 \%, n=50)$. However, it is likely that a new pre-offer block acquisition by an active control specialist/arbitrager ensures that offers are fair to begin with.

\subsection{Block acquisitions and the buyout outcome}

Takeover specialists can increase returns to shareholders, either by taking over the firm themselves or by facilitating a takeover by a higher third party bidder (see Holderness and Sheehan, 1986; Jensen and Ruback, 1983). Thus, professional investors can influence who acquires the firm as well as the price paid for the firm.

Table 7 shows that the success of an outside party takeover is positively correlated with a new post-offer block acquisition by an active control specialist/arbitrager. All of these takeovers occur at a higher price than that offered by management. Thus, this finding supports the hypothesis that professional investors are more likely to acquire a block when the management bid is 'low'. In contrast, there is no significant correlation between the success of an outside party takeover and a new pre-offer block acquisition by a control specialist/arbitrager who takes actions either before or after the offer. However, it is unlikely that managers make an MBO offer without 
receiving the prior cooperation of large blockholders. An outside party takeover is also significantly correlated with a new post-offer block acquisition by a corporation. These companies are likely to acquire a 'toe-hold' to increase the probability of a successful bid (see Walking, 1985; Edminster and Walking, 1985). Finally, an outside party takeover is significantly and negatively correlated with the level of inside holdings and old 13D outside holdings. This finding is consistent with Stulz's (1988) prediction that large inside holdings give managers the power to resist an outside takeover. This finding also suggests that old 13D blockholders are aligned with management during the buyout contest.

Table 7 reports the results of a multivariate logit regression. A block acquisition made after the offer by an active control specialist/arbitrager continues to significantly increase the likelihood of an outside party takeover. Four out of 24 or $20 \%$ of these takeovers are completed by control specialists/arbitragers, and the remaining $80 \%$ are completed by corporations. Overall, the evidence indicates that control specialists both 'facilit(ate) transfers of control' to a thirdparty at a higher price and 'take control' of the firm for themselves (see Jensen and Ruback, 1983). These findings are consistent with those of other researchers. Mikkelson and Ruback (1985) find that there are acquisitions by frequent purchasers who rarely take over the firm; Holderness and Sheehan (1985) find that after a block acquisition by a 'raider' three firms are reorganized by the raiders themselves, whereas ten firms are reorganized by third parties.

\section{Summary and conclusion}

I document changes in outside blockholdings around MBO attempts. Outside ownership concentration increases around the time of an MBO offer. Much of the increase takes the form of newly accumulated blocks held temporarily by professional investors who play an active role in the buyout contest. Their participation increases the likelihood that the MBO fails, and the firm is taken over by either the professional investor or a higher third-party bidder. The overall weight of the evidence supports the hypothesis that block acquisitions by professional investors increase buyout premiums earned by shareholders.

While the findings of this study are specific to the role of ownership structure in MBO contests, they also have general

Journal of Financial Economics, Vol. 40, No. 2 (February 1996): pg. 267-294. DOI. This article is (c Elsevier and permission has been granted for this version to appear in e-Publications@Marquette. Elsevier does not grant permission for this article to be further copied/distributed or hosted elsewhere without the express permission from Elsevier. 
implications for that role in the firm. Demsetz and Lehn (1985) explain cross-sectional variation in ownership structure by looking at different characteristics of firms at the same point in 'calendar time'. Rather than observing cross-sectional variation in the levels of outside ownership, my research investigates changes in outside ownership concentration conditional on a particular event, the announcement of an MBO offer. This is an example of the general proposition that incentives to concentrate outside ownership are likely to vary over time, as the value of corporate control changes. Other examples are provided by Dodd and Warner (1983), who find that the value of the vote attached to shares increases around proxy contests, and Gilson (1990), who finds outside block ownership increases in firms undergoing bankruptcy. Other major corporate events are potential areas for future research.

Finally, this research adds to the recent empirical literature on the various roles of blockholders in monitoring management (see Holderness and Sheehan 1985; Brickley, Lease, and Smith, 1988; Barclay and Holderness, 1989). Different types of blockholders are likely to have different comparative advantages in monitoring various types of managerial activities. In an MBO contest, managers have an inherent conflict of interest with shareholders since they have no incentive to offer their best price for the firm. The evidence presented in this study indicates that pre-existing blockholders do not actively negotiate during the MBO contest. Instead, new blockholders who are control specialists provide these negotiating benefits to shareholders.

\section{Acknowledgments:}

- Useful comments and suggestions were received from workshop participants at Arizona State University, S.U.N.Y. Buffalo, University of South Carolina, and University of Iowa; Michael J. Barclay, Daniel W. Collins, Michael C. Jensen (the editor), Bruce W. Johnson, Marc R. Reinganum, Clifford W. Smith Jr., and an anonymous referee. I am grateful to Jerold B. Warner for especially helpful comments. Research support from the Managerial Economics Research Center at the University of Rochester is gratefully acknowledged.

\section{Notes}

- ${ }^{1}$ I am grateful for Steven Kaplan's generosity in supplying his sample. This sample consists of both successful and unsuccessful management buyouts. The successful buyouts include all buyouts of at least $\$ 100$ million that are announced or completed between 1984 and 1987 . He also includes an incomplete sample of buyouts

Journal of Financial Economics, Vol. 40, No. 2 (February 1996): pg. 267-294. DOI. This article is (C Elsevier and permission has been granted for this version to appear in e-Publications@Marquette. Elsevier does not grant permission for this article to be further copied/distributed or hosted elsewhere without the express permission from Elsevier. 
that are worth less than $\$ 100$ million. The failed buyouts include all failed buyouts announced between 1984 and 1985 of at least $\$ 50$ million.

- $\quad 2$ The blockholders in the sample whom I classify as frequent acquirers are: Victor Posner, Asher Edelman, the Bass brothers, Paul Bilzerian, Ivan Boesky, Carl Icahn, Irwin Jacobs, Samuel Belzberg, the Dart Group, Ronald Perelman, and David Murdoch. Examples of some of the blockholders in my sample that I classify as equity-holding companies are: Jamie Securities Co., Gabelli Group, and Mutual Shares Corp.

- ${ }^{3}$ Following Brickley, Lease, and Smith (1988), I classify the following investors as institutional investors: insurance companies, banks, nonbank trusts, pension fund trusts, mutual funds, endowments, private pension funds, brokerage houses, investment counsel firms, and miscellaneous financial service firms.

- $\quad 4$ There are two active new post-offer blockholders (an investment counsel firm and a miscellaneous financial service firm) included as control specialists/arbitragers in the tests reported in Tables 6 and 7.

\section{References}

Barclay, M.J. and C.G. Holderness, 1989, Negotiated block trades and corporate control, Unpublished working paper (University of Rochester, Rochester, NY).

Bradley, Michael, 1980, Interfirm tender offers and the market for corporate control, Journal of Business 53, 345-376.

Bradley, Michael, Anand Desai, and E. Han Kim, 1988, Synergistic gains from corporate acquisitions and their division between the stockholders of target and acquiring firms, Journal of Financial Economics 21, 3-40.

Brickley, James A., Jeffrey L. Coles, and Rory L. Terry, 1994, Outside directors and the adoption of poison pills, Journal of Financial Economics 35, 371-390.

Brickley, James A., R.C. Lease, and C.W. Smith, Jr., 1988, Ownership structure and voting on antitakeover amendments, Journal of Financial Economics 20, 267-291.

Byrd, John W. and Kent A. Hickman, 1992, Do outside directors monitor managers? Evidence from tender offer bids, Journal of Financial Economics 32, 195-221.

Dann, Larry Y. and DeAngelo, Harry, 1988, Corporate policy and corporate control: A study of defensive adjustments in asset and ownership structure, Journal of Financial Economics 20, 87-127.

DeAngelo, Harry and Linda DeAngelo, 1987, Management buyouts of publicly traded corporations, Financial Analysts Journal, May-June, 38-49.

Journal of Financial Economics, Vol. 40, No. 2 (February 1996): pg. 267-294. DOI. This article is (C Elsevier and permission has been granted for this version to appear in e-Publications@Marquette. Elsevier does not grant permission for this article to be further copied/distributed or hosted elsewhere without the express permission from Elsevier. 
NOT THE PUBLISHED VERSION; this is the author's final, peer-reviewed manuscript. The published version may be accessed by following the link in the citation at the bottom of the page.

DeAngelo, Harry, Linda DeAngelo, and E. Rice, 1984, Going private: Minority freezeouts and stockholder wealth, Journal of Law and Economics 11,401-438.

Demsetz, Harold and Kenneth Lehn, 1985, The structure of corporate ownership: Causes and consequences, Journal of Political Economy 93, 1155-1177.

Dodd, Peter and Jerold B. Warner, 1983, On corporate governance: A study of proxy contests, Journal of Financial Economics 11, 401-438.

Edminster, Robert O. and Ralph A. Walking, 1985, Determinants of tender offer premiums, Financial Analysts Journal, Jan.-Feb., 27-37.

Gilson, Stuart C., 1990, Bankruptcy, boards, banks and blockholders: Evidence on changes in corporate ownership when firms default, Journal of Financial Economics 27, 355-387.

Grossman, Sanford J. and Oliver D. Hart, 1980, Takeover bids, the free-rider problem and the theory of the corporation, Bell Journal of Economics $11,42-64$.

Harris, Milton and Artur Raviv, 1988, Corporate control contests and capital structure, Journal of Financial Economics 20, 203-235.

Holderness, Clifford G. and Dennis P. Sheehan, 1985, Raiders or saviors? The evidence on six controversial investors, Journal of Financial Economics 14, 555-579.

The Insider's Chronicle, Summary of insider transactions (Andrew R. Mandala, Bethesda, MD) various volumes.

Jarrell, Gregg A., 1985, The wealth effects of litigation by targets: Do interests in a merge diverge?, Journal of Law and Economics XXBIII, 151-177.

Jensen, Michael C. and Richard S. Ruback, 1983, The market for corporate control: The scientific evidence, Journal of Financial Economics 11, 550.

Jensen, Michael C. and Jerold B. Warner, 1988, The distribution of power among corporate managers, shareholders and directors, Journal of Financial Economics 20, 3-24.

Kaplan, Steven, 1989, The effects of management buyouts on operating performance and value, Journal of Financial Economics 24, 217-254.

Lowenstein, Louis, 1985, Management buyouts, Columbia Law Review 85, 730-784.

Manne, Henry G., 1965, Mergers and the market for corporate control, Journal of Political Economy 73, 110-120.

Mikkelson, Wayne H. and Richard S. Ruback, 1985, An empirical analysis of the interfirm equity investment process, Journal of Financial Economics 14, 523-553.

Miller, Gregory, 1986, Where's the hot money going?, Institutional Investor, May, 137-148.

Journal of Financial Economics, Vol. 40, No. 2 (February 1996): pg. 267-294. DOI. This article is (C) Elsevier and permission has been granted for this version to appear in e-Publications@Marquette. Elsevier does not grant permission for this article to be further copied/distributed or hosted elsewhere without the express permission from Elsevier. 
Roe, Mark J., 1990, Political and legal constraints on ownership and control of public companies, Journal of Financial Economics 27, 7-41.

Shleifer, A. and R.W. Vishny, 1986, Large shareholders and corporate control, Journal of Political Economy 94, 461-488.

Smith, Abbie J., 1990, Corporate ownership structure and performance: The case of management buyouts, Journal of Financial Economics 27,143164.

Stulz, René, M., 1988, Managerial control of voting rights: Financing policies and the market for corporate control, Journal of Financial Economics 20, 24-54.

Walking, Ralph A., 1985, Predicting tender offer success: A logistic analysis, Journal of Financial and Quantitative Analysis 1, 461-478.

Standard \& Poor's Corporation, Security owner's stock guide (S\&P, New York, NY) various volumes.

\section{Appendix}

Table 1. Frequency of outcomes of management buyout attempts for a sample of 111 firms in the period 1984 to 1987 . A management buyout attempt is defined as any announcement in which management, either alone or with a group of equity investors, makes an offer to buy the firm. Management-initiated buyouts are buyouts in which management made the first offer to buy the firm. Outside-party initiated buyouts are buyouts in which an outside party made the first offer to buy the firm. Failed buyouts are firms that continue to have publicly traded stock two years after the initial buyout offer. Number of firms in each category is reported (percentage of total sample in parentheses)

\begin{tabular}{|l|c|c|c|c|}
\hline & $\begin{array}{c}\text { Successful } \\
\text { management } \\
\text { buyouts }\end{array}$ & $\begin{array}{c}\text { Successful } \\
\text { outside party } \\
\text { takeovers }\end{array}$ & $\begin{array}{c}\text { Failed } \\
\text { buyouts }\end{array}$ & $\begin{array}{c}\text { Total number } \\
\text { of firms }\end{array}$ \\
\hline $\begin{array}{c}\text { Management } \\
\text { initiated buyouts }\end{array}$ & $\begin{array}{c}60 \\
(54.05 \%)\end{array}$ & $\begin{array}{c}21 \\
(18.42 \%)\end{array}$ & $\begin{array}{c}13 \\
(11.71 \%)\end{array}$ & $\begin{array}{c}94 \\
(84.68 \%)\end{array}$ \\
\hline $\begin{array}{l}\text { Outside-party } \\
\text { initiated buyouts }\end{array}$ & 13 & 3 & 1 & 17 \\
\hline $\begin{array}{l}\text { Total number of } \\
\text { firms }\end{array}$ & $(11.71 \%)$ & $(2.70 \%)$ & $(0.90 \%)$ & $(15.32 \%)$ \\
\hline
\end{tabular}

Journal of Financial Economics, Vol. 40, No. 2 (February 1996): pg. 267-294. DOI. This article is (C) Elsevier and permission has been granted for this version to appear in e-Publications@Marquette. Elsevier does not grant permission for this article to be further copied/distributed or hosted elsewhere without the express permission from Elsevier. 
NOT THE PUBLISHED VERSION; this is the author's final, peer-reviewed manuscript. The published version may be accessed by following the link in the citation at the bottom of the page.

Table 2. Chronology of events during management buyout attempts for a sample of 111 firms in the period 1984 to 1987. A management buyout attempt is defined as any announcement in which management, either alone or with a group of equity investors, makes an offer to buy the firm. The cumulative number of firms with occurrence of event by month-end is reported.

\begin{tabular}{|c|c|c|c|c|c|c|c|c|}
\hline \multirow[b]{2}{*}{ Event types } & \multicolumn{5}{|c|}{$\begin{array}{l}\text { Cumulative number of firms with event (months } \\
\text { relative to MBO offer): }\end{array}$} & \multirow{2}{*}{$\begin{array}{l}\text { Percentage } \\
\text { of total }\end{array}$} & \multirow{2}{*}{$\begin{array}{l}\text { Average percentage } 3 \text {-day } \\
\text { cumulative abnormal return } \\
\text { around event } \text { ( } z \text {-statisic) }^{b}\end{array}$} & \multirow{2}{*}{$\begin{array}{l}\text { Number of firms } \\
\text { with event before } \\
\text { the MBO offer }\end{array}$} \\
\hline & +1 & +3 & +6 & +12 & +24 & & & \\
\hline Competitive bid & 9 & 18 & 19 & 19 & 25 & $22.5 \%$ & $\begin{array}{l}7.89 \% \\
(13.20)^{h}\end{array}$ & 5 \\
\hline $\begin{array}{l}\text { Management } \\
\text { revises offer }\end{array}$ & 15 & 34 & 49 & 53 & 54 & $48.6 \%$ & $\begin{array}{l}7.87 \% \\
(15.86)^{t}\end{array}$ & ก.a. \\
\hline $\begin{array}{l}\text { Managerial } \\
\text { resistance to } \\
\text { outside-party } \\
\text { takoover" }\end{array}$ & 2 & 9 & 10 & 13 & 18 & $16.2 \%$ & $\begin{array}{l}0.28 \% \\
(1.07)\end{array}$ & 41 \\
\hline $\begin{array}{l}\text { Block } \\
\text { acquisition' }\end{array}$ & 12 & 20 & 27 & 29 & 32 & $28.8 \%$ & $\begin{array}{l}5.49 \% \\
(9.13)^{6}\end{array}$ & 36 \\
\hline $\begin{array}{l}\text { Blockholder } \\
\text { takes some } \\
\text { type of actions }\end{array}$ & 19 & 26 & 30 & 30 & 33 & $29.7 \%$ & $\begin{array}{l}13.05 \% \\
(31.82)^{h}\end{array}$ & 21 \\
\hline $\begin{array}{l}\text { Minority } \\
\text { shareholder } \\
\text { litigation }\end{array}$ & 24 & 32 & 36 & 41 & 44 & $39.6 \%$ & $\begin{array}{l}-0.42 \% \\
(-0.55)\end{array}$ & 2 \\
\hline $\begin{array}{l}\text { Committee of } \\
\text { independent } \\
\text { director }\end{array}$ & n.a. & n.a. & n.a. & na. & n.a. & $64.2 \%$ & n.a. & n.a. \\
\hline $\begin{array}{l}\text { Independent } \\
\text { directors rejoct } \\
\text { management's } \\
\text { bid }\end{array}$ & 3 & 7 & 7 & 8 & 8 & $7.7 \%$ & $\begin{array}{l}3.62 \% \\
(3.08)^{n}\end{array}$ & n.a. \\
\hline
\end{tabular}

n.a. = not applicable.

${ }^{a}$ Cumulative abnormal returns are the summation of abnormal returns on day $-1,0$, +1 . Day 0 is the day the event was announced in the Wall Street Journal or came over the Dow Jones News Wire. Abnormal returns are calculated as the difference between realized returns and market-model expected returns. The CRSP (NASDAQ) valueweighted index is used as the market index for CRSP (NASDAQ) firms. The market model is estimated using 200 daily returns 120 days prior to the initial buyout announcement.

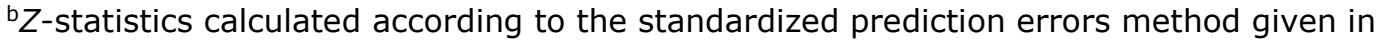
the Appendix of Dodd and Warner (1983).

'The time period is 12 months before the MBO offer to the month of the MBO offer. ${ }^{d}$ Competitive bid is defined as any bid from an outside party (other than a blockholder) after the initial offer.

eManagerial resistance is defined as taking anyone of the following actions: (1) adopting an antitakeover amendment; (2) litigating an outside bidder; (3) increasing management's effective stake by buying back shares, debt for equity swap, repurchase of convertible preferred or convertible debt for cash, private placement of equity, or repurchase of shares from an investor.

${ }^{f}$ Report of a SEC 13D filing of a block acquisition of $5 \%$ or more in either the Wall Street Journal or the Dow Jones News Wire.

gBlockholder actions are defined as reports in the financial press of blockholder statements or actions other than changes in shareholdings, alone.

hSignificant at the $1 \%$ level.

Journal of Financial Economics, Vol. 40, No. 2 (February 1996): pg. 267-294. DOI. This article is (C) Elsevier and permission has been granted for this version to appear in e-Publications@Marquette. Elsevier does not grant permission for this article to be further copied/distributed or hosted elsewhere without the express permission from Elsevier. 
NOT THE PUBLISHED VERSION; this is the author's final, peer-reviewed manuscript. The published version may be accessed by following the link in the citation at the bottom of the page.

Table 3. Increases in blockholdings around management buyout attempts for a sample of 111 firms in the period 1984 to 1987 . A management buyout attempt is defined as any announcement in which management, either alone or with a group of equity investors, makes an offer to buy the firm.

\begin{tabular}{|c|c|c|c|}
\hline & $\begin{array}{l}\text { New pre-offer } \\
\text { blockholders" }\end{array}$ & $\begin{array}{l}\text { New post-offer } \\
\text { blockholders }^{\circ}\end{array}$ & Old blockholders ${ }^{c}$ \\
\hline $\begin{array}{l}\text { Average percentage shares outstanding } \\
\text { acquired before } \mathrm{MBO} \text { announcement } \\
\text { (number of blockholders) }\end{array}$ & $\begin{array}{l}9.88 \\
(55)\end{array}$ & n.a. & $\begin{array}{l}8.04 \\
(4)\end{array}$ \\
\hline $\begin{array}{l}\text { Average percentage shares outstanding } \\
\text { acquired after MBO announcement } \\
\text { (number of blockholders) }\end{array}$ & $\begin{array}{c}5.96 \\
(8)\end{array}$ & $\begin{array}{l}7.11 \\
(35)\end{array}$ & $\begin{array}{c}5.39 \\
(4)\end{array}$ \\
\hline $\begin{array}{l}\text { Average number of days block } \\
\text { acquisition made before MBO } \\
\text { announcement }{ }^{d} \text { (median) }\end{array}$ & $\begin{array}{c}123.71 \\
(92)\end{array}$ & n.a. & $\begin{array}{l}268.8 \\
(308)\end{array}$ \\
\hline $\begin{array}{l}\text { Average number of days block } \\
\text { acquisition made after MBO } \\
\text { announcement }{ }^{d} \text { (median) }\end{array}$ & $\begin{array}{c}55.13 \\
(17)\end{array}$ & $\begin{array}{c}142.86 \\
(124)\end{array}$ & $\begin{array}{l}85.5 \\
(42)\end{array}$ \\
\hline
\end{tabular}

n.a. = not applicable.

aNew post-offer blockholders are those whose initial 13D filing is announced between 30 days and up to 24 months after the management buyout offer.

${ }^{b}$ New pre-offer blockholders are those whose initial 13D filing is announced between 12 months prior to the management buyout offer and up to 30 days after the management buyout offer.

cOld blockholders are those who own shares 12 months prior to the management buyout offer.

dThe number of days used is for the first block acquisition after the MBO announcement, and for the first block acquisition before the MBO announcement when there are multiple acquisitions.

Journal of Financial Economics, Vol. 40, No. 2 (February 1996): pg. 267-294. DOI. This article is @ Elsevier and permission has been granted for this version to appear in e-Publications@Marquette. Elsevier does not grant permission for this article to be further copied/distributed or hosted elsewhere without the express permission from Elsevier. 
NOT THE PUBLISHED VERSION; this is the author's final, peer-reviewed manuscript. The published version may be accessed by following the link in the citation at the bottom of the page.

Table 4. Number of different types of blockholders for a sample of 111 firms with a management buyout attempt in the period 1984 to 1987 . A management buyout attempt is defined as any announcement in which management, either alone or with a group of equity investors, makes an offer to buy the firm.

\begin{tabular}{|c|c|c|c|c|}
\hline Type of blockholder & $\begin{array}{c}\text { New } \\
\text { pre-offer } \\
\text { blockholders }\end{array}$ & $\begin{array}{l}\text { New post-offer } \\
\text { blockholders }^{a}\end{array}$ & $\begin{array}{l}\text { Old blockholders } \\
\text { who acquire } \\
\text { more shares }^{a}\end{array}$ & $\begin{array}{l}\text { Old blockholders } \\
\text { who do not acquire } \\
\text { more shares" }\end{array}$ \\
\hline \multicolumn{5}{|c|}{ Control specialists/arbitragers } \\
\hline $\begin{array}{l}\text { Equity-holding } \\
\text { company }\end{array}$ & 19 & 17 & 2 & $11^{1}$ \\
\hline Frequent acquirer ${ }^{c}$ & 15 & 7 & 3 & 2 \\
\hline Total & 34 & 24 & 5 & 13 \\
\hline \multicolumn{5}{|l|}{ Other } \\
\hline $\begin{array}{l}\text { Miscellaneous } \\
\text { corporation }^{\text {d }}\end{array}$ & 12 & 6 & 0 & 7 \\
\hline $\begin{array}{l}\text { Miscellaneous } \\
\text { individual }^{*}\end{array}$ & 3 & 0 & 0 & 23 \\
\hline $\begin{array}{l}\text { Unidentified investor } \\
\text { group }\end{array}$ & 1 & 1 & 1 & 2 \\
\hline $\begin{array}{l}\text { Member of funding } \\
\text { family }\end{array}$ & 0 & 0 & 0 & 3 \\
\hline Total & 16 & 7 & 1 & 35 \\
\hline \multicolumn{5}{|l|}{ Institutional investors } \\
\hline Insurance company & 0 & 0 & 0 & 8 \\
\hline Bank & 0 & 0 & 0 & 17 \\
\hline Nonbank trust & 0 & 0 & 0 & 4 \\
\hline Public pension fund & 0 & 0 & 0 & 1 \\
\hline Mutual fund & 0 & 0 & 0 & 21 \\
\hline Brokerage house' & 0 & 0 & 0 & 1 \\
\hline $\begin{array}{l}\text { Investment counsel } \\
\text { firm }^{g}\end{array}$ & 2 & 1 & 2 & 14 \\
\hline $\begin{array}{l}\text { Miscellaneous } \\
\text { financial services } \\
\text { firm" }\end{array}$ & 2 & 3 & 1 & 15 \\
\hline $\begin{array}{l}\text { Unidentified } \\
\text { institutional investor }\end{array}$ & 0 & 0 & 0 & 5 \\
\hline Total & 4 & 4 & 3 & 86 \\
\hline Active & 28 & 17 & 6 & 7 \\
\hline Passive & 27 & 18 & 3 & 127 \\
\hline Total & 55 & 35 & 9 & 134 \\
\hline
\end{tabular}

aSee notes Table 3.

bExamples of some of the blockholders in my sample that I classify as equity-holding companies are: Jamie Securities Co., Gabelli Group, and Mutual Shares Corp.

'The blockholders in the sample whom I classify as frequent acquirers are: Victor Posner, Asher Edelman, the Bass brothers, Paul Bilzerian, Ivan Boesky, Carl Icahn, Irwin Jacobs, Samuel Belzberg, the Dart Group, Ronald Perelman, and David Murdock. ${ }^{\mathrm{d} A}$ miscellaneous corporation is company that does not provide financial services of any kind. An example of some of the firms in my sample that I classify as miscellaneous corporations are Macmillan, Inc., Pillsbury, and Fisher Foods, Inc. ${ }^{\mathrm{e}} \mathrm{A}$ miscellaneous individual is an individual other than a frequent acquirer. Examples of individuals that I classify as miscellaneous in my sample are Beth A. Vanderberg, Mrs. Daryl D. Jones, and Steven J. Kumble. 
NOT THE PUBLISHED VERSION; this is the author's final, peer-reviewed manuscript. The published version may be accessed by following the link in the citation at the bottom of the page.

${ }^{f}$ Blockholders are classified as brokerage houses if that is the characterization in the proxy statement or the financial press. The one brokerage house in my sample is Spear, Leeds, \& Kellog.

gBlockholders are classified as investment counsel firms if that is the characterization in the proxy statement or the financial press. Examples of investment counsel firms in my sample are First Pacific Advisors, Inc., Templeton Investment Counsel, Inc., and William D. Witt, Inc.

hMiscellaneous financial services firms are firms that provide several financial services, including investment banking services. Examples of miscellaneous financial service firms in my sample are Donaldson, Lufkin, \& Jenrette, T. Rowe Price Associates, PaineWebber Inc.

'Active blockholders are those who are reported as taking some type of action other than the acquisition of shares during the 12 months prior to the MBO offer or afterwards.

jChi-square tests are used to test various associations; the association between new blockholder types and whether the block is acquired pre-offer or post-offer is not statistically significant at conventional levels; the association between new blockholder types and old blockholder types is statistically significant at the $1 \%$ level; the association between whether the new block is acquired pre-offer or post-offer and the blockholder's active participation in the contest is not statistically significant at conventional levels; and the association between whether the blockholder is new or old, and the blockholder's active participation in the contest is statistically significant at the $1 \%$ level.

Journal of Financial Economics, Vol. 40, No. 2 (February 1996): pg. 267-294. DOI. This article is @ Elsevier and permission has been granted for this version to appear in e-Publications@Marquette. Elsevier does not grant permission for this article to be further copied/distributed or hosted elsewhere without the express permission from Elsevier. 
NOT THE PUBLISHED VERSION; this is the author's final, peer-reviewed manuscript. The published version may be accessed by following the link in the citation at the bottom of the page.

Table 5. Number of different types of actions taken by different typesa of blockholders around a management buyout attempt for a sample of 111 firms in the period 1984 to 1987.b A management buyout attempt is defined as any announcement in which management, either alone or with a group of equity investors, makes an offer to buy the firm (percentage of total actions shown in parentheses).

\begin{tabular}{|c|c|c|c|c|c|c|}
\hline \multicolumn{7}{|c|}{ Panel A: Actions taken by new post-offer blockholders } \\
\hline $\begin{array}{c}\text { Type of } \\
\text { blockhoider }\end{array}$ & Bidding & $\begin{array}{l}\text { Thwart } \\
\text { MBO } \\
\text { attempt }\end{array}$ & $\begin{array}{l}\text { Participate in } \\
\text { restructuring }\end{array}$ & $\begin{array}{l}\text { Accept } \\
\text { side } \\
\text { payment }\end{array}$ & $\begin{array}{l}\text { Take } \\
\text { over the } \\
\text { firm }\end{array}$ & Total \\
\hline $\begin{array}{l}\text { Equity-holding } \\
\text { company }\end{array}$ & 12 & 4 & 3 & 0 & 3 & $\begin{array}{c}22^{6} \\
(53.66 \%)\end{array}$ \\
\hline Frequent acquirer & 0 & 0 & 2 & 0 & 0 & $\begin{array}{c}2 \\
(4.88 \%)\end{array}$ \\
\hline $\begin{array}{l}\text { Miscellaneous } \\
\text { corporation }\end{array}$ & 8 & 0 & 3 & 1 & 3 & $\begin{array}{c}15 \\
(36.59 \%)\end{array}$ \\
\hline $\begin{array}{l}\text { Investment } \\
\text { counsel firm }\end{array}$ & 0 & 1 & 0 & 0 & 0 & $\begin{array}{c}1 \\
(2.44 \%)\end{array}$ \\
\hline $\begin{array}{l}\text { Miscellaneous } \\
\text { financial services } \\
\text { firm }\end{array}$ & 0 & 1 & 0 & 0 & 0 & $\begin{array}{c}1 \\
(2.44 \%)\end{array}$ \\
\hline Total & $\begin{array}{c}20 \\
(48.78 \%)\end{array}$ & $\begin{array}{c}6 \\
(14.63 \%)\end{array}$ & $\begin{array}{c}8 \\
(19.51 \%)\end{array}$ & $\begin{array}{c}1 \\
(2.44 \%)\end{array}$ & $\begin{array}{c}6 \\
(14.63 \%)\end{array}$ & $\begin{array}{c}41 \\
(100 \%)\end{array}$ \\
\hline \multicolumn{7}{|c|}{$\begin{array}{l}\text { Panel B: Actions taken by new pre-offer blockholders (actions taken before the offer, actions } \\
\text { taken after the offer) }\end{array}$} \\
\hline $\begin{array}{l}\text { Type of } \\
\text { blockholder }\end{array}$ & Bidding & $\begin{array}{l}\text { Thwart } \\
\text { MBO } \\
\text { attempt }\end{array}$ & $\begin{array}{l}\text { Participate in } \\
\text { restructuring }\end{array}$ & $\begin{array}{l}\text { Accept a } \\
\text { side } \\
\text { payment }\end{array}$ & $\begin{array}{l}\text { Take } \\
\text { over the } \\
\text { firm }\end{array}$ & Total \\
\hline $\begin{array}{l}\text { Equity-holding } \\
\text { company }\end{array}$ & $\begin{array}{c}1 \\
(1,0)\end{array}$ & $\begin{array}{c}4 \\
(2,2)\end{array}$ & $\begin{array}{c}4 \\
(2,2)\end{array}$ & $\begin{array}{c}1 \\
(0,1)\end{array}$ & $\begin{array}{c}0 \\
(n, a, 0)\end{array}$ & $\begin{array}{c}10 \\
(13.33 \%)\end{array}$ \\
\hline Frequent acquirer & $\begin{array}{c}18 \\
(12,6)\end{array}$ & $\frac{12+1}{7}$ & $\frac{(2,14}{8}$ & $(1,1)$ & $\frac{1}{(n, a, 1)}$ & $\begin{array}{c}36 \\
(48.00 \%)\end{array}$ \\
\hline $\begin{array}{l}\text { Miscellaneous } \\
\text { corporation }\end{array}$ & $\begin{array}{l}10 \\
(3,7)\end{array}$ & $\begin{array}{c}6 \\
(3,3)\end{array}$ & $\begin{array}{c}5 \\
(3,2)\end{array}$ & $\begin{array}{c}0 \\
(0,0)\end{array}$ & $\begin{array}{c}2 \\
\text { (n.a., 2) }\end{array}$ & $\begin{array}{c}23 \\
(30.67 \%)\end{array}$ \\
\hline Brokerage house & $\begin{array}{c}0 \\
0.0)\end{array}$ & $\begin{array}{c}3 \\
(0,3)\end{array}$ & $\begin{array}{c}0 \\
0 \\
(0.0)\end{array}$ & $\begin{array}{c}0 \\
(0,0)\end{array}$ & $\begin{array}{c}0 \\
\text { (n.a. o) }\end{array}$ & $\begin{array}{c}3 \\
(4.00 \%)\end{array}$ \\
\hline $\begin{array}{l}\text { Unidentified } \\
\text { investor group }\end{array}$ & $\begin{array}{c}1 \\
(0,1)\end{array}$ & $\begin{array}{c}0 \\
(0.0)\end{array}$ & $\begin{array}{c}0 \\
(0,0)\end{array}$ & $\begin{array}{c}0 \\
(0,0)\end{array}$ & $\begin{array}{c}0 \\
(\text { n.a. }, 0)\end{array}$ & $\begin{array}{c}1 \\
(1.33 \%)\end{array}$ \\
\hline $\begin{array}{l}\text { Miscellaneous } \\
\text { individual }\end{array}$ & $\begin{array}{c}0 \\
(0,0)\end{array}$ & $\begin{array}{c}2 \\
(1,1)\end{array}$ & $\begin{array}{c}0 \\
(0,0)\end{array}$ & $\begin{array}{c}0 \\
(0,0)\end{array}$ & $\begin{array}{c}0 \\
(\text { n.a. o })\end{array}$ & $\begin{array}{c}2 \\
(2.67 \%)\end{array}$ \\
\hline Total & $\begin{array}{c}30 \\
(40.00 \%)\end{array}$ & $\begin{array}{c}22 \\
(29.33 \%)\end{array}$ & $\begin{array}{c}17 \\
(22.67 \%)\end{array}$ & $\begin{array}{c}3 \\
(4.00 \%)\end{array}$ & $\begin{array}{c}3 \\
(4.00 \%)\end{array}$ & $\begin{array}{c}75 \\
(100 \%)\end{array}$ \\
\hline
\end{tabular}

n.a. = not applicable.

${ }^{a}$ For definitions of different types, see notes to Tables 3 and 4.

bThe time period is 12 months before the MBO offer until the buyout is completed, or 24 months after the MBO offer in the case of failed buyouts.

${ }^{c} \mathrm{Chi}$-square tests are used to test various associations: The association between blockholder type and action type is statistically significant at the $10 \%$ level for postblock acquisitions only; the association between types of blockholders taking actions and whether the block is a acquired before or after the MBO offer is statistically significant at the $1 \%$ level; the association between types of actions and whether the block is a acquired before or after the MBO offer is not statistically significant; and the association between types of actions taken by new pre-offer blockholders and whether the action is taken before or after the MBO offer is not statistically significant. 
NOT THE PUBLISHED VERSION; this is the author's final, peer-reviewed manuscript. The published version may be accessed by following the link in the citation at the bottom of the page.

Table 6. The relation between a higher offer from either management or an outside third-party other than a blockholder after an initial management buyout offer and ownership structure and contest events for a sample of 111 firms in the period 1984 to 1987. A management buyout offer is defined as any announcement in which management, either alone or with a group of equity investors, makes an offer to buy the firm ( $p$-value for significance of coefficient in parentheses).

\begin{tabular}{|c|c|c|}
\hline Independent variables & $\begin{array}{l}\text { Spearman rank } \\
\text { correlations between a } \\
\text { higher offer after an } \\
\text { MBO offer and } \\
\text { independent variables }\end{array}$ & $\begin{array}{c}\text { Coefficient estimates from a } \\
\text { logit regression of a dummy } \\
\text { variable for a higher offer after } \\
\text { an MBO offer on independent } \\
\text { variables }\end{array}$ \\
\hline Intercept & - & $\begin{array}{l}0.3791 \\
(0.39)\end{array}$ \\
\hline Managerial resistance to takeover & $\begin{array}{l}0.02 \\
(0.83)\end{array}$ & $\begin{array}{r}-0.7346 \\
(0.15)\end{array}$ \\
\hline $\begin{array}{l}\text { Independent directors reject } \\
\text { management's bid }\end{array}$ & $\begin{array}{c}0.11 \\
(0.24)\end{array}$ & $\begin{array}{l}0.7283 \\
(0.56)\end{array}$ \\
\hline Minority shareholder litigation & $\begin{array}{l}-0.02 \\
(0.82)\end{array}$ & $\begin{array}{l}-0.0670 \\
(0.87)\end{array}$ \\
\hline Size (total equity vale) $)^{r}$ & $\begin{array}{l}0.16 \\
(0.10)\end{array}$ & $\begin{array}{c}8.75 \times 10^{7} \\
(0.18)\end{array}$ \\
\hline Inside holdings ${ }^{d}$ & $\begin{array}{l}-0.137 \\
(0.18)\end{array}$ & $\begin{array}{c}-1.4033 \\
(0.19)\end{array}$ \\
\hline Institutional holdings" & $\begin{array}{l}0.08 \\
(0.39)\end{array}$ & $\begin{array}{l}-0.1249 \\
(0.49)\end{array}$ \\
\hline Old 13D holdings' & $\begin{array}{l}-0.04 \\
(0.68)\end{array}$ & $\begin{array}{l}0.4876 \\
(0.88)\end{array}$ \\
\hline $\begin{array}{l}\text { New pre-offer blockhoider is a } \\
\text { control specialist/arbitrager and is } \\
\text { passive? }\end{array}$ & $\begin{array}{c}0.12 \\
(0.20)\end{array}$ & $\begin{array}{l}1.3680 \\
(0.08)\end{array}$ \\
\hline $\begin{array}{l}\text { New pre-offer blockholder is a } \\
\text { control specialist/arbitrager and is } \\
\text { active before the offer }\end{array}$ & $\begin{array}{l}0.01 \\
(0.93)\end{array}$ & $\begin{array}{l}0.9431 \\
(0.26)\end{array}$ \\
\hline $\begin{array}{l}\text { New pre-offer blockholder is a } \\
\text { control specialistlarbitrager and is } \\
\text { active after the offer }\end{array}$ & $\begin{array}{c}0.16 \\
(0.10)\end{array}$ & $\begin{array}{l}-0.5151 \\
(0.53)\end{array}$ \\
\hline $\begin{array}{l}\text { New pre-offer blockholder is a } \\
\text { corporation? }\end{array}$ & $\begin{array}{l}-0.03 \\
(0.76)\end{array}$ & $\begin{array}{l}-0.8540 \\
(0.36)\end{array}$ \\
\hline $\begin{array}{l}\text { New post-offer blockholder is a } \\
\text { control specialist/arbitrageur and is } \\
\text { passive }\end{array}$ & $\begin{array}{c}0.16 \\
(0.10)\end{array}$ & $\begin{array}{l}1.0216 \\
(0.13)\end{array}$ \\
\hline $\begin{array}{l}\text { New post-offer blockholder is a } \\
\text { control specialistlarbitrageur and is } \\
\text { active }^{0}\end{array}$ & $\begin{array}{l}0.18 \\
(0.06)\end{array}$ & $\begin{array}{l}1.5742 \\
(0.20)\end{array}$ \\
\hline $\begin{array}{l}\text { New post-offer blockholder is a } \\
\text { corporation }\end{array}$ & $\begin{array}{r}0.09 \\
(0.36)\end{array}$ & $\begin{array}{l}0.3088 \\
(0.81)\end{array}$ \\
\hline
\end{tabular}

${ }^{a}$ All firm characteristics measured during the period 12 months prior to the MBO offer to the higher offer. For firms with no higher offer measured to the buyout completion, or 24 months after the MBO offer in the case of failed buyouts.

bSee notes to Table 2.

'Total equity value is the number of shares outstanding times price per share one month prior to the initial buyout offer.

${ }^{\mathrm{d}}$ Inside holdings are measured 12 months prior to the MBO offer.

eInstitutional holdings are total monthly institutional holdings measured in the month of the MBO offer.

fOld 13D outside holdings are total 13D holdings measured 12 months prior to the MBO offer.

9For definitions of blockholder types see notes to Tables 3 and 4.

Journal of Financial Economics, Vol. 40, No. 2 (February 1996): pg. 267-294. DOI. This article is (C Elsevier and permission has been granted for this version to appear in e-Publications@Marquette. Elsevier does not grant permission for this article to be further copied/distributed or hosted elsewhere without the express permission from Elsevier. 
NOT THE PUBLISHED VERSION; this is the author's final, peer-reviewed manuscript. The published version may be accessed by following the link in the citation at the bottom of the page.

Table 7. The relation between the successful takeover of the firm by an outside party and ownership structure and contest events for a sample of 111 firms in the period 1984 to 1987. A management buyout offer is defined as any announcement in which management, either alone or with a group of equity investors, makes an offer to buy the firm ( $p$-value for significance of coefficient in parentheses).

\begin{tabular}{|c|c|c|}
\hline Independent variables ${ }^{a}$ & $\begin{array}{c}\text { Spearman rank } \\
\text { correlations between an } \\
\text { outside-party takeover } \\
\text { and independent } \\
\text { variables }\end{array}$ & $\begin{array}{l}\text { Coefficient estimates from } \\
\text { a logit regression of a } \\
\text { dummy variable for an } \\
\text { outside-party takeover on } \\
\text { independent variables }\end{array}$ \\
\hline Intercept & - & $\begin{array}{c}-1.1056 \\
(0.08)\end{array}$ \\
\hline Number of competitive bids & $\begin{array}{l}0.48 \\
(0.00)\end{array}$ & $\begin{array}{l}0.6629 \\
(0.00)\end{array}$ \\
\hline Managerial resistance to takeover & $\begin{array}{l}-0.02 \\
(0.87)\end{array}$ & $\begin{array}{l}-0.6200 \\
(0.39)\end{array}$ \\
\hline $\begin{array}{l}\text { Independent directors reject } \\
\text { management's bid }\end{array}$ & $\begin{array}{c}0.19 \\
(0.04)\end{array}$ & $\begin{array}{l}2.0418 \\
(0.08)\end{array}$ \\
\hline Minority shareholder litigation & $\begin{array}{l}-0.10 \\
(0.28)\end{array}$ & $\begin{array}{c}-1.2528 \\
(0.10)\end{array}$ \\
\hline Size (total equity value) & $\begin{array}{l}-0.02 \\
(0.84)\end{array}$ & $\begin{array}{c}-1.266 \times 10^{-7} \\
(0.88)\end{array}$ \\
\hline Inside holdings & $\begin{array}{l}-0.17 \\
(0.08)\end{array}$ & $\begin{array}{c}-3.1910 \\
(0.17)\end{array}$ \\
\hline Institutional holdings & $\begin{array}{l}-0.01 \\
(0.93)\end{array}$ & $\begin{array}{l}-0.0339 \\
(0.93)\end{array}$ \\
\hline Old $13 \mathrm{D}$ outside holdings & $\begin{array}{l}-0.18 \\
(0.05)\end{array}$ & $\begin{array}{c}-4.9529 \\
(0.60)\end{array}$ \\
\hline $\begin{array}{l}\text { New pre-offer blockholder is a control } \\
\text { specialist/arbitrager and is passive }\end{array}$ & $\begin{array}{c}0.03 \\
(0.73)\end{array}$ & $\begin{array}{c}-0.3666 \\
(0.71)\end{array}$ \\
\hline $\begin{array}{l}\text { New pre-offer blockholder is a control } \\
\text { specialist/arbitrager and is active } \\
\text { before the offer }\end{array}$ & $\begin{array}{l}0.01 \\
(0.89)\end{array}$ & $\begin{array}{c}-1.2025 \\
(0.29)\end{array}$ \\
\hline $\begin{array}{l}\text { New pre-offer blockholder is a control } \\
\text { specialist/arbitrager and is active after } \\
\text { the offer }\end{array}$ & $\begin{array}{l}0.05 \\
(0.61)\end{array}$ & $\begin{array}{l}1.7378 \\
(0.10)\end{array}$ \\
\hline New-offer blockholder is a corporation & $\begin{array}{c}0.08 \\
(0.38)\end{array}$ & $\begin{array}{l}0.0865 \\
(0.94)\end{array}$ \\
\hline $\begin{array}{l}\text { New post-offer blockholder is a control } \\
\text { specialist/arbitrager and is passive }\end{array}$ & $\begin{array}{c}0.05 \\
(0.60)\end{array}$ & $\begin{array}{c}-0.3642 \\
(0.66)\end{array}$ \\
\hline $\begin{array}{l}\text { New post-offer blockholder is a control } \\
\text { specialist and is active }\end{array}$ & $\begin{array}{c}0.37 \\
(0.00)\end{array}$ & $\begin{array}{l}2.4237 \\
(0.02)\end{array}$ \\
\hline $\begin{array}{l}\text { New post-offer blockholder is a } \\
\text { corporation }\end{array}$ & $\begin{array}{c}0.16 \\
(0.08)\end{array}$ & $\begin{array}{l}1.1141 \\
(0.39)\end{array}$ \\
\hline
\end{tabular}

aFor definitions of independent variables, see notes to Table 6. 
NOT THE PUBLISHED VERSION; this is the author's final, peer-reviewed manuscript. The published version may be accessed by following the link in the citation at the bottom of the page.

\section{Figure 1}

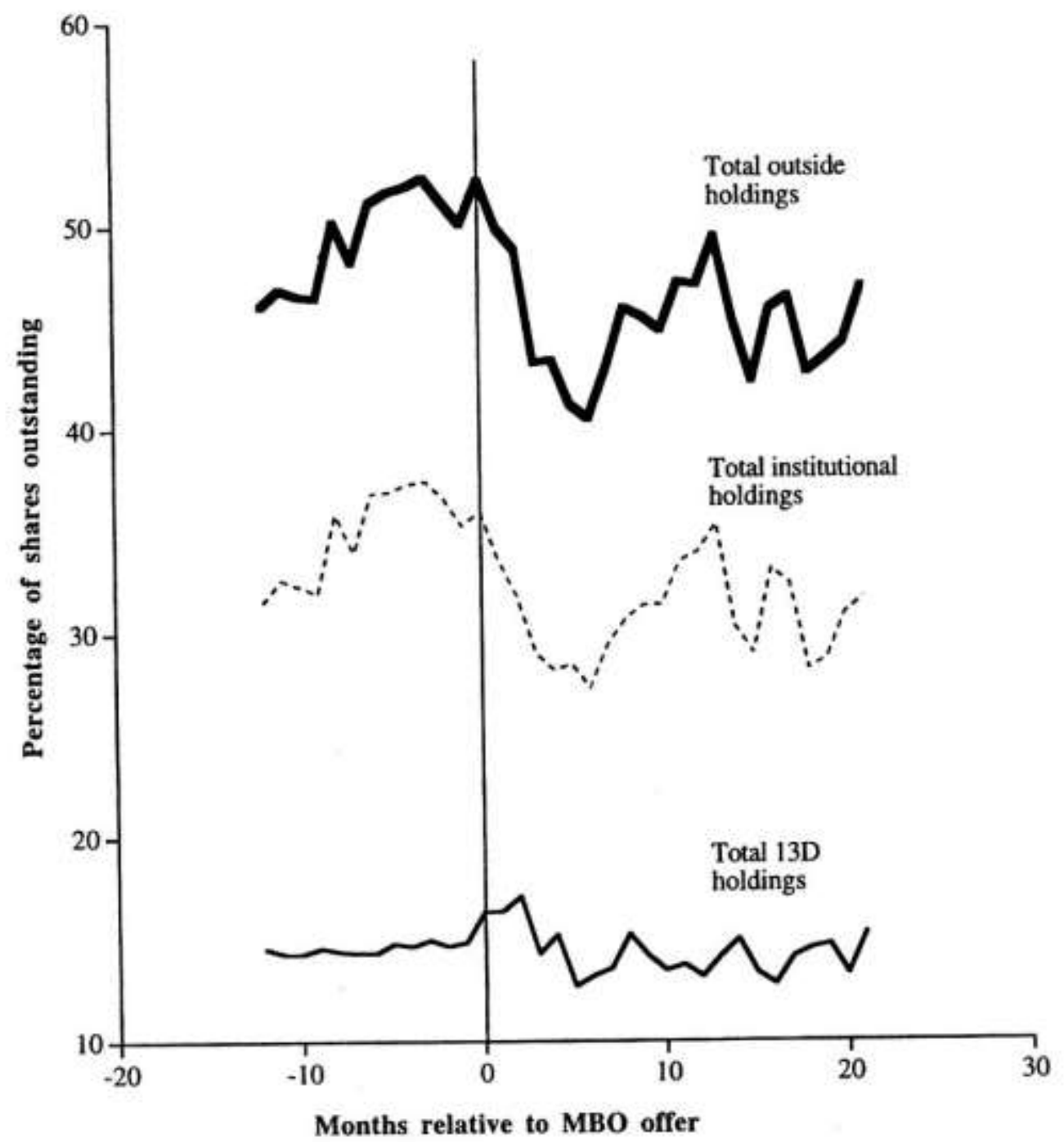

Average level of monthly outside blockholdings around management buyout attempts for a sample of 111 firms in the period 1984 to 1987. A management buyout attempt is defined as any announcement in which management, either alone or with a group of equity investors, makes an offer to buy the firm. Total institutional holdings for each firm is the total percentage of shares outstanding held by all institutional investors (both $13 \mathrm{~F}$ and $13 \mathrm{G}$ filers). Total 13D holdings for each firm is the sum of each 13D blockholder's highest holdings within that month. Total outside holdings is the sum of total institutional and total 13D holdings. 